УДК 619:612.12:616.995.1:636.2

(C) 2016

Шевченко Т. С., зоотехнік-селекціонер

(науковий керівник - доктор ветеринарних наук, професор В. О. Свстаф'єва)

СПП «РВД-Агро» Черкаського району Черкаської області

\title{
БІОХІМІЧНІ ПОКАЗНИКИ СИРОВАТКИ КРОВІ МОЛОДНЯКУ ВЕЛИКОЇ РОГАТОЇ ХУДОБИ ЗА ТРИХУРОЗНОЇ ІНВАЗІї
}

\section{Рецензент - кандидат ветеринарних наук Н. І. Дмитренко}

У роботі наведені дані біохімічних показників сироватки крові великої рогатої худоби 6-12-місячного віку за трихурозної інвазії. Встановлено, щсо паразитування збудника в організмі тварин призводить до змін з боку біохімічних показників, зокрема: у хворого на трихуроз молодняку великої рогатої худоби, в порівнянні з клінічно здоровими тваринами, у сироватщі крові значно знижується кількість альбумінів (на $32,7 \%, P<0,01$ ), азоту сечовини (на 23,8\%, $P<0,05$ ), креатиніну (на 44,1\%, $P<0,05$ ), кальцію (на 28,6\%, $P<0,001)$ та каротину (на 32,4\%, $P<0,05)$. Водночас встановлене достовірне підвищення рівня $\mathrm{AcAm}$ (в 2,7 рази, $P<0,001$ ) та індексу де Pimica (в 2,4 рази, $P<0,001)$.

Ключові слова: велика рогата худоба, трихуроз, біохімічні показники, сироватка крові.

Постановка проблеми. Своєрідні природнокліматичні умови України сприяють розведенню великої рогатої худоби, від якої населення отримує не тільки м'ясні та молочні продукти, а і сировину для текстильної промисловості. На зниження якості продукції скотарства впливають поширені на даний час гельмінтозні захворювання, зокрема трихуроз великої рогатої худоби [3].

Заходи профілактики та лікування гельмінтозів дають змогу уникнути економічного збитку, заподіяного в результаті значного зниження приросту молодняку, затримкою його розвитку, а також зменшенням кількості та якості продукції тваринництва [12].

Трихуриси, проникаючи головним кінцем у слизову оболонку кишківника, викликають запалення, набряки, необоротні зміни в місцях локалізації. Крім того, гельмінти здатні перетравлювати своїми протеолітичними секретами навколишні тканини дефінітивних хазяїв, тим самим посилюючи механічний вплив паразитів на шлунково-кишковий тракт $[2,11]$.

Аналіз основних досліджень і публікацій, у яких започатковано розв'язання проблеми. Дослідженням трихурозу жуйних займалися здебільшого науковці Російської Федерації та Мол- дови [8]. Беззаперечно, збудники трихурозу чинять патогенний вплив на організм, призводячи до змін як в органах, так і у кровоносному руслі хворих тварин. Отримати більш повне уявлення про патогенез трихурозної інвазії можливо, визначивши біохімічні зміни у сироватці крові хворих тварин. За даними досліджень С. Ю. Пігіної [9], на 15-й день зараження збудником трихурозу у тварин відмічали підвищення рівня загального білірубіну на 2,9 \%, прямого білірубіну - на $46,1 \%$, креатиніну - на $60,8 \%$ і на $48,3 \%$ сечовини. Крім того, спостерігали зниження активності амілази на 26,1 \%, порівняно 3 показниками дослідних тварин до зараження. Через 55 днів після інвазування тварин зміни в біохімічних показниках сироватки крові були менш вираженими, за винятком амілази, активність якої залишалася зниженою на 26,1 \%.

У жуйних, зокрема в овець, у разі паразитування трихурисів у організмі погіршується перетравність і засвоюваність життєво важливих поживних речовин: протеїну - на 5,4 \%, жиру - на $2,6 \%$, клітковини - на 9,5\%, кальцію - на 4,2 \%, фосфору - на 2,1\%, порівняно 3 клінічно здоровими тваринами $[1,4]$.

Мета досліджень полягала у визначенні впливу трихурозної інвазії на біохімічні показники сироватки крові великої рогатої худоби.

Завданням досліджень було визначити зміни біохімічних показників сироватки крові у великої рогатої худоби за трихурозу і провести їх аналіз.

Матеріали і методи досліджень. Дослідження проводилися впродовж літньо-осіннього періоду 2015 року в умовах сільськогосподарського приватного підприємства «РВД-Агро» Черкаського району. Біохімічні показники сироватки крові визначали на базі сертифікованого науководослідного центру біобезпеки та екологічного контролю ресурсів АПК Дніпропетровського державного аграрно-економічного університету 3 використанням автоматичного біохімічного аналізатора TARGA BT 3000 Plus (Італія) та реактивів фірми «HUMAN» (Німеччина). Підготовка 


\section{СІЛЬСЬКЕ ГОСПОДАРСТВО. ТВАРИННИЦТВО}

проб для дослідження та методика його проведення були виконані згідно 3 інструкцією до приладу та матеріалів.

Дослід проводили на телицях 6-12-місячного віку, які перебували в однакових умовах утримання та годівлі. 3 відібраних тварин було сформовано дослідну (хворі на трихуроз із II=37,6 $\pm 5,3$ яєць у 1 грамі фекалій) та контрольну (клінічно здорові) групи, по 5 голів у кожній. Копроовоскопічні дослідження проводили на базі наукової лабораторії паразитології кафедри паразитології та ветеринарно-санітарної експертизи Полтавської державної аграрної академії за методикою В. Н. Трача [10].

Кров для досліджень відбирали зранку до годівлі тварин, 3 підхвостової вени. У сироватці крові досліджуваних телиць визначали вміст загального білку, альбумінів, глобулінів, білковий коефіцієнт, сечовину, азот сечовини, креатинін, аспартатамінотрансферазу (АсАт), аланінамінотрансферазу (АлАт), індекс де Рітіса (АсАт/АлАт), лужну фосфатазу, кількість глюкози, кальцію, неорганічного фосфору, співвідношення кальцію до фосфору $(\mathrm{Ca} / \mathrm{P})$, ліпопротеїди та каротин.

Статистичну обробку результатів дослідження проводили за допомогою комп'ютерної програми MS Excel 2003. Визначали середнє арифме- тичне (M) та похибку (m), за результатами яких, використовуючи таблицю t-критеріїв Ст'юдента [6], був встановлений рівень вірогідності даних (p).

Результати дослідження. У великої рогатої худоби, інвазованої збудником трихурозу, встановлені достовірні зміни у біохімічних показниках сироватки крові (див. табл.).

Згідно з отриманими даними у сироватці крові хворих на трихуроз телиць відмічається достовірне зниження кількості альбумінів на $32,7 \%$ (30,0 $\pm 3,03$ г/л, $\mathrm{P}<0,01$, порівняно 3 показниками клінічно здорових тварин 44,6 $\pm 1,50$ г/л), азоту сечовини на $23,8 \%(6,4 \pm 0,56$ мг $\%, \mathrm{P}<0,05$, порів-

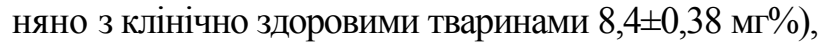
креатиніну на 44,1 \% (65,6 $\pm 11,30$ мкмоль/л, $\mathrm{P}<0,05$, проти показників у здорових 117,4 $\pm 10,60$ мкмоль/л),

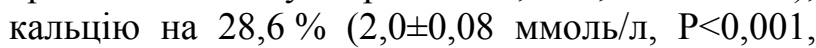
тоді як у здорових показники 2,8 $\pm 0,12$ ммоль/л) та каротину на 32,4 \% $(238,0 \pm 24,90$ мг\%, $\mathrm{P}<0,05$,

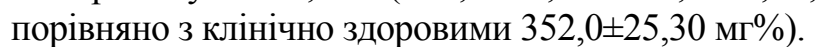

Також відмічали значне підвищення рівня АсАт в 2,7 рази $(101,0 \pm 10,00$ Од/л, $\mathrm{P}<0,001$, порівняно 3 показниками у клінічно здорових телиць 37,2 $\pm 2,59$ Од/л), що стало результатом підвищення індексу де Рітіса в 2,4 рази $(3,1 \pm 0,30$ од., $\mathrm{P}<0,001$, порівняно 3 клінічно здоровими тваринами 1,3 $\pm 0,06$ од.).

\section{Біохімічні показники клінічно здорових та хворих на трихуроз телиць за низької інтенсивності інвазї $(M \pm m, n=5)$}

\begin{tabular}{|c|c|c|c|}
\hline Показники & $\begin{array}{c}\text { Клінічно здорові } \\
\text { телиці }\end{array}$ & $\begin{array}{c}\text { Телиці, хворі на } \\
\text { трихуроз }\end{array}$ & $\begin{array}{c}\text { Фізіологічні } \\
\text { коливання }\end{array}$ \\
\hline Загальний білок, г/л & $75,2 \pm 2,63$ & $64,8 \pm 4,22$ & $70-85$ \\
\hline Альбуміни, г/л & $44,6 \pm 1,50$ & $30,0 \pm 3,03 * *$ & $40-50$ \\
\hline Глобуліни, г/л & $32,6 \pm 0,60$ & $34,8 \pm 5,10$ & $25-41$ \\
\hline Білковий коефіціснт, од. & $0,9 \pm 0,10$ & $0,9 \pm 0,18$ & $0,6-1,1$ \\
\hline Сечовина, ммоль/л & $3,7 \pm 0,28$ & $3,4 \pm 0,29$ & $3-6$ \\
\hline Азот сечовини, мг\% & $8,4 \pm 0,38$ & $6,4 \pm 0,56^{*}$ & $8-14$ \\
\hline Креатинін, мкмоль/л & $117,4 \pm 10,60$ & $65,6 \pm 11,30^{*}$ & $80-130$ \\
\hline АсАт, Од/л & $37,2 \pm 2,59$ & $101,0 \pm 10,00^{* * *}$ & $10-50$ \\
\hline АлАт, Од/л & $28,8 \pm 1,62$ & $34,8 \pm 6,19$ & $10-30$ \\
\hline Індекс де Рітіса & $1,3 \pm 0,06$ & $3,1 \pm 0,30 * * *$ & $1,0-3,4$ \\
\hline (АсАт/АлАт), од. & $124,0 \pm 11,10$ & $105,0 \pm 15,50$ & $100-200$ \\
\hline Лужна фосфатаза, Од/л & $2,8 \pm 0,09$ & $2,4 \pm 0,17$ & $2,5-3,5$ \\
\hline Глюкоза, ммоль/л & $2,8 \pm 0,12$ & $2,0 \pm 0,08^{* * *}$ & $2,4-3,2$ \\
\hline Кальцій, ммоль/л & $1,8 \pm 0,08$ & $1,5 \pm 0,14$ & $1,5-2,2$ \\
\hline Неорганічний фосфор, ммоль/л & $1,5 \pm 0,02$ & $1,3 \pm 0,09$ & $1,2-1,6$ \\
\hline Са/Р, од. & $514,0 \pm 71,68$ & $362,0 \pm 64,20$ & $400-800$ \\
\hline Ліпопротеїди заг., мг\% & $352,0 \pm 25,30$ & $238,0 \pm 24,90^{*}$ & $275-965$ \\
\hline Каротин, мг\% &
\end{tabular}

Примітка: * - $<<0,05 ; * *-p<0,01 ; * * *-p<0,001$ - відносно показників клінічно здорових тварин;

- фізіологічні коливання показників подані за В. В. Влізло та ін. (2008) [5] та Д. О. Мельничуком та ін. (2010) [7]. 


\section{СІЛЬСЬКЕ ГОСПОДАРСТВО. ТВАРИННИЦТВО}

У інвазованих збудником трихурозу тварин встановлене зниження загального білку на $13,8 \% \quad(64,8 \pm 4,22$ г/л) та глюкози на $14,3 \%$ (2,4 $\pm 0,17$ ммоль/л), порівняно 3 показниками клінічно здорових тварин $(75,2 \pm 2,63$ г/л, 2,8 $\pm 0,09$ ммоль/л відповідно), і підвищення рівня АлАт на

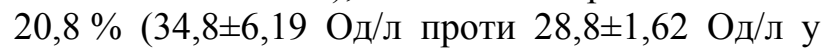
клінічно здорових), та ці показники не мали вірогідних значень. Глобуліни, білковий коефіцієнт, сечовина та лужна фосфатаза знаходилися у межах фізіологічних коливань.

Отже, у великої рогатої худоби, спонтанно інвазованої збудником трихурозу, за низької інтенсивності інвазії відбувається значне ураження печінки (про що свідчить високий рівень АсАт, зниження кількості альбумінів і азоту сечовини) та порушення з боку шлунково-кишкового тракту, яке проявляється у недостатньому засвоєнні поживних речовин (на що вказує зниження у сироватці крові креатиніну, кальцію і каротину). На нашу думку, такі зміни в печінці відбуваються внаслідок інтоксикації організму хворих тва-

\section{БІБЛІОГРАФІЯ}

1. Гареев A. Г. Трихоцефалез овец и разработка рациональных мер борьбы с ним в условиях Башкирского Южного Урала (эпизоотология, патогенез, клиническая картина, терапия и профилактика) : дисс. ... к.вет.н. : спец. 03.00.19 «Паразитология»/ А. Г. Гареев. - Уфа, 1983. $235 \mathrm{c}$.

2. Крючкова E. Н. Динамика формирования микропаразитоценозов в кишечнике овец при трихоцефалезе / Е. Н. Крючкова, Ю. Ф. Петров // Тез. доклад 3 всес. съезда паразитоцентологов. Киев, 1991. - С. 85.

3. Кльосов М. Д. Поширення і динаміка найголовніших гельмінтозів с.-г. тварин у Запорізькій, Дніпропетровській, Полтавській, Вінницькій та Кам'янець-Подільській областях і в Молдавії / М. Д. Кльосов, С. А. Гнатюк, М. Я. Бекерман // Наук. праці УІЕВ. - 1941. - Т. 10. - С. 127-158.

4. Крючкова E. Н. Динамика гематологических и некоторых биохимических показателей у овец при трихоцефалезе / Е. Н. Крючкова, Ю. Ф. Петров // Сборник науч. тр. Ивановского СХИ и ЛВИ. Иваново, 1991. - С. 40-44.

5. Лабораторна діагностика у ветеринарній медицині : довідник / [Влізло В. В., Максимович І. А., Галяс В. Л., Леньо М. І.]. - Львів, 2008. - 112 с.

6. Лапач С. Н. Статистические методы в медико-биологических исследованиях с использо- рин продуктами життєдіяльності гельмінтів. Зміни у шлунково-кишковому тракті зумовлені властивістю трихурисів проникати своїм головним кінцем у слизову оболонку кишечника, таким чином здійснюючи постійний механічний вплив на його стінку, руйнуючи кровоносні судини та погіршуючи засвоєння поживних речовин.

\section{Висновки:}

1. У спонтанно інвазованих збудником трихурозу телиць 6-12-місячного віку, з інтенсивністю інвазії 37,6 $\pm 5,30$ яєць в 1 грамі фекалій, у сироватці крові встановлено достовірне зниження кількості альбумінів (на 32,7\%, Р<0,01), азоту сечовини (на 23,8\%, $\mathrm{P}<0,05$ ), креатиніну (на $44,1 \%, \mathrm{P}<0,05$ ), кальцію (на 28,6\%, Р<0,001) та каротину (на $32,4 \%, \mathrm{P}<0,05$ ).

2. Відмічається значне підвищення рівня АсАт у 2,7 рази $(101,0 \pm 10,00$ Од/л, $\mathrm{P}<0,001$, порівняно 3 показниками у клінічно здорових телиць $37,2 \pm 2,59$ Од/л) та індексу де Рітіса в 2,4 рази (3,1 $\pm 0,30$ од., $\mathrm{P}<0,001$ проти показників у клінічно здорових тварин 1,3 $\pm 0,06$ од.).

ванием Excel / С. Н. Лапач, А. В. Чубенко, П. Н. Бабич. - К. : Морион, 2001. - 320 с.

7. Ветеринарна клінічна біохімія : навчальний посібник / [Мельничук Д. О., Мельничук С. Д., Грищенко В. А. та ін.]. - К., 2010. - 451 с.

8. Пасечник B. E. Эколого-эпизоотологические основы профилактики трихоцефалеза овец в республике Молдова : дисс. ... к.вет.н. : 03.00.19 «Паразитология» / В. Е. Пасечник. - М., 2000. $195 \mathrm{c}$.

9. Пигина С. Ю. Эпизоотология трихоцефалеза крупного рогатого скота в условиях Северного Кавказа и разработка оптимальных доз антигельминтиков : автореф. дисс. на соиск. уч. степени к.вет.н. : спец. 03.00.19 «Паразитология» / С. Ю. Пигина. - М., 2007. - 250 с.

10. Трач В. Н. Рекомендации по применению нового метода учёта яиц гельминтов и цист простейших в фекалиях животных / В. Н. Трач. - К., 1992. - 13 c.

11. Шихобалова Н. П. Трихоцефалез (эпидемиология и иммунитет) : дисс ... д.мед.н. : 03.00.19 «Паразитология» / Н. П. Шихобалова. M., 1948. $-256 \mathrm{c}$.

12. Becklund $W$. W. Helminthiasio of sheep in southern Georgia / W. W. Becklund // Veterin. Med. Assoc. - USA, 1961. - V. 139. - №7. - P. 781784. 